\title{
Typologia strategii oszczędnościowych wiejskich gospodarstw domowych (na przykładzie województwa małopolskiego)
}

\section{Wstęp}

Globalizacja rynków finansowych i towarzyszący jej coraz intensywniejszy proces internacjonalizacji instytucji finansowych nie pozostają bez wpływu na konsumenta i jego zachowania na rynku. Wzrost wagi tej problematyki poteggowany jest także rozwojem technologicznym, rozszerzeniem oferty rynkowej dostępnej dla konsumentów oraz zmianami cywilizacyjno-kulturowymi [Smyczek 2014, s. 97].

W globalnej gospodarce rynkowej, wśród różnych obszarów zachowań konsumenta na rynku, szczególne miejsce zajmują zachowania finansowe przebiegające na rynkach finansowych. Zachowania te odnoszą się do wyborów konsumenta podczas poszukiwania, zakupów, użytkowania, oceny oraz rozdysponowania usług finansowych, które zaspokajają jego potrzeby [Smyczek 2012, s. 58-59].

W teoriach dotyczących zachowań finansowych gospodarstw domowych szczególna uwaga poświęcona jest kwestii gromadzenia oszczędności. Punkt wyjścia w analizach zachowań oszczędnościowych gospodarstw domowych stanowią teorie dochodowe Keynesa oraz Friedmana, a także teoria cyklu życia Modiglianiego i Brumberga. Pierwsza z wymienionych teorii - hipoteza dochodu absolutnego - zakłada, że poziom konsumpcji uzależniony jest od dochodu bieżącego. Z kolei, według teorii dochodu permanentnego Friedmana, wydatki konsumpcyjne gospodarstw domowych zależą w głównej mierze od dochodu stałego (permanentnego), rozumianego jako przeciętny dochód uzyskiwany w ciagu całego życia konsumenta. Teoria cyklu życia wyróżnia dwa okresy: czas 
pracy, w trakcie którego jednostka akumuluje bogactwo, oraz czas emerytury, kiedy jednostka może skorzystać ze zgromadzonego w czasie pracy bogactwa, co pozwala na utrzymanie określonego standardu życia nawet w okresie uzyskiwania mniejszych dochodów [Ando i Modigliani 1963, s. 56].

Teorie dochodowe i teoria cyklu życia zakładają w pełni racjonalne zachowania jednostek, które w praktyce nie występują. W 1975 roku Katona stwierdził, że najważniejszą rolę w kształtowaniu zachowań nabywców odgrywają czynniki o charakterze psychologicznym, a oszczędzanie jest wypadkową zdolności i chęci oszczędzania [Garczarczyk i in. 2014, s. 18]. W ślad za tym autorem w nurcie prac z zakresu ekonomii powszechnie przyjmuje się, że konsumenci na rynku działają z ograniczoną racjonalnością.

W 1988 roku Shefrin i Thaler stworzyli behawioralną hipotezę cyklu życia bazującą na samokontroli (ang. self-control) i systemie księgowania umysłowego (ang. mental accounting). Podstawą tej teorii nie tylko była analiza zachowań racjonalnych, ale także rzeczywiste ludzkie zachowanie. Badania nad efektem samokontroli prowadzili także Rha, Montalto i Hanna, udowadniając w nich, że gospodarstwa domowe, które stosowały się do ustanowionych zasad oszczędzania (ang. saving rules) więcej oszczędziły niż te, które takich zasad nie stosowały. Mental accounting polega na dokonywaniu w procesie podejmowania decyzji mentalnej kalkulacji zysków i strat. Proces rachunkowości mentalnej jest zróżnicowany w zależności od wybranej strategii finansowej realizowanej przez gospodarstwa domowe [Bańbuła 2006, s. 50].

Jak wynika z badań krajowych [Kata 2010, s. 144; Kuśmierczyk 2011, s. 33; Maciejasz-Świątkiewicz 2012, s. 45] i zagranicznych [Deirdre 2007, s. 53], strategie oszczędnościowe realizowane przez gospodarstwa domowe różnią się w zależności od miejsca zamieszkania konsumentów (miasto lub wieś). Jak wskazują Kata i inni [2015, s. 8], przyczyny zróżnicowania zachowań finansowych pomiędzy mieszkańcami miast i wsi leżą zarówno po stronie popytowej, jak i podażowej. Do tych pierwszych należy zaliczyć małe dochody ludności wiejskiej oraz czynniki behawioralne i edukacyjne. $Z$ kolei po stronie podażowej należy wskazać słaby rozwój infrastruktury finansowej na obszarach niezurbanizowanych, niedopasowanie oferty usług do potrzeb lokalnych klientów oraz asymetrię informacji.

Strategie finansowe gospodarstw domowych są także zróżnicowane regionalnie. Pewnych informacji na ten temat dostarczają badania empiryczne dotyczące sytuacji życiowej Polaków, przeprowadzone w ramach projektu Diagnoza Społeczna. W świetle tych badań zdecydowanie najrzadziej posiadanie oszczędności deklarowały gospodarstwa domowe $\mathrm{z}$ województw warmińsko-mazurskiego (70\% z nich nie posiadło żadnych oszczędności) i kujawsko-pomorskiego (prawie 65\%) [Czapiński i Panek 2015, s. 56]. Różnice w skłonności 
do oszczędzania gospodarstw domowych w zależności od przynależności administracyjnej do danego województwa zostały zauważone również w badaniach przeprowadzonych przez TNS Polska dla Związku Banków Polskich [TNS Polska 2014, s. 16-17].

Mając na uwadze regionalne zróżnicowanie zachowań oszczędnościowych konsumentów, jak również różnice w zachowaniach finansowych między miejskimi i wiejskimi gospodarstwami domowymi, konieczne wydaje się poznanie specyfiki zachowań oszczędnościowych wybranych grup konsumentów. Otrzymane informacje mogą posłużyć do przeprowadzenia segmentacji klientów instytucji finansowych, budowy przez nie skutecznych strategii marketingowych, stworzenia oferty produktów dopasowanych do mieszkańców wsi, co bezpośrednio może wpłynąć na wzrost poziomu inkluzji finansowej na obszarach wiejskich.

Głównym celem pracy jest identyfikacja i charakterystyka poszczególnych typów strategii oszczędnościowych wiejskich gospodarstw domowych w województwie małopolskim, a także określenie motywów, którymi kierują się konsumenci, podejmując decyzje o oszczędzaniu.

\section{Metody badań}

Podstawowym źródłem danych do analizy i wnioskowania były informacje pierwotne pochodzące $\mathrm{z}$ badań własnych. $\mathrm{W}$ badaniach wykorzystano technikę wywiadu osobistego. Badania miały charakter badań regionalnych. Zakres przestrzenny badań objął wiejskie obszary województwa małopolskiego.

Badania przeprowadzono w 2014 roku na grupie 384 respondentów. Doboru respondentów dokonano metodą doboru warstwowego proporcjonalnego. Warstwami (grupami) próby były podregiony województwa małopolskiego według klasyfikacji GUS [2013, s. 96-97]. Struktura próby badawczej pod względem podregionu zamieszkania i płci odpowiadała populacji generalnej.

Wśród osób, które uczestniczyły w badaniu, 54\% stanowiły kobiety, a 46\% mężczyźni. W badaniach brały udział tylko osoby pełnoletnie (powyżej 18. roku życia). Prawie $45 \%$ badanych stanowiły osoby w wieku $18-35$ lat, $36 \%$ osoby w wieku 36-55 lat. Co piąty respondent miał powyżej 55 lat. Najliczniejsza grupa respondentów miała wykształcenie wyższe $(49 \%)$. Osoby z wykształceniem średnim stanowiły $36 \%$ ogółu badanych. Pozostali respondenci deklarowali wykształcenie zawodowe. Duży udział osób z wykształceniem wyższym wynika $\mathrm{z}$ tego, że osoby te chętniej wyrażały chęć udziału w badaniach. Dominująca grupa respondentów były osoby pracujące ( $2 / 3$ badanych). W badaniach wzięli udział także studenci (19\%), emeryci i renciści (9\%). Najmniej liczną grupa 
byli bezrobotni (8\%). Dominowały czteroosobowe gospodarstwa domowe oraz gospodarstwa, w których przeciętny miesięczny poziom dochodu netto na osobę w rodzinie mieścił się w przedziale 501-1000 zł.

Do realizacji wyznaczonego celu zastosowano wskaźniki struktury oraz niehierarchiczną metodę analizy skupień - grupowanie metodą $k$-średnich. Celem tej metody jest wyodrębnienie homogenicznych grup konsumentów przy zachowaniu minimalizacji zmienności wewnątrz skupień oraz maksymalizacji zmienności między poszczególnymi skupieniami [Stanisz 2007, s. 127-128]. $\mathrm{W}$ celu porównania otrzymanych wyników $\mathrm{z}$ innymi badaniami w analizie przyjęto podział populacji na sześć skupień (sześć strategii oszczędnościowych) według Anioły i Gołasia [2013b, s. 78]. Wyniki badań zostały przedstawione w formie opisowej i graficznej (tabele i wykresy).

\section{Portfel oszczędnościowy wiejskich gospodarstw domowych}

Oszczędności gospodarstw domowych są częścią dochodu, która nie jest przeznaczona do spożycia i która jest przechowywana w gotówce, instrumentach finansowych i zasobach rzeczowych [Korenik 2003, s. 119]. Jednym z kryteriów podziału oszczędności jest ich dobrowolność gromadzenia. Na podstawie tego kryterium w wąskim zakresie wyróżnia się oszczędzanie dobrowolne i przymusowe. Oszczędzanie dobrowolne oznacza świadomą, wolną od zewnętrznych nacisków rezygnację gospodarstwa domowego z wydatkowania części swych dochodów na bieżące cele konsumpcyjne. O oszczędzaniu przymusowym mówimy wówczas, gdy rezygnacja z wydatkowania części dochodów na konsumpcję odbywa się pod przymusem prawnym (np. obowiązkowe składki emerytalne) lub przymusem ekonomicznym (w warunkach deficytu towarów na rynku) [Bywalec 2009, s. 163]. W niniejszym opracowaniu analizie poddano tylko oszczędności o charakterze dobrowolnym.

Podstawowym kryterium analitycznym wykorzystywanym w badaniu zachowań oszczędnościowych gospodarstw domowych jest skłonność do oszczędzania mierzona odsetkiem gospodarstw deklarujących posiadanie oszczędności [Anioła i Gołaś 2012, s. 37]. Jak wynika z przeprowadzonych badań, prawie $40 \%$ analizowanych gospodarstw domowych posiadało oszczędności. Otrzymane rezultaty są zbieżne z wnioskami badania Diagnozy Społecznej, z których wynika, że w 2013 roku oszczędności posiadało 41\% polskich gospodarstw domowych, a w 2015 roku odpowiednio 45\% [Czapiński i Panek 2015, s. 56]. Oszczędności posiadały w równym stopniu kobiety i mężczyźni, głównie osoby 
w wieku 35-54 lat, osoby najlepiej wykształcone oraz gospodarstwa domowe posiadające największy dochód netto przypadający na osobę w rodzinie.

Drugim wskaźnikiem charakteryzującym zachowania oszczędnościowe gospodarstw domowych jest stopa oszczędzania mierzona relacją poziomu oszczędności gospodarstwa domowego do jego dochodów [Anioła i Gołaś 2012, s. 38]. W grupie oszczędzających gospodarstw domowych $(n=150)$ tylko $35 \%$ jednostek posiadało oszczędności większe od trzymiesięcznych dochodów gospodarstwa. Wyniki te są na niższym poziomie niż rezultaty uzyskane w badaniu Diagnoza Społeczna, w świetle którego prawie 42\% Polaków w 2013 roku deklarowało oszczędności na poziomie wyższym niż trzymiesięczne dochody gospodarstwa domowego [Czapiński i Panek 2015, s. 56]. Otrzymana różnica wynika $\mathrm{z}$ tego, że rezultaty zamieszczone we wspomnianym raporcie dotyczą całej populacji Polaków, a w niniejszym opracowaniu próba została zawężona do mieszkańców wsi jednego z województw.

Mimo znaczącego rozwoju rynku usług finansowych w Polsce w ostatnim okresie oraz wzrostu aktywności promocyjnej instytucji finansowych, Polacy preferują tradycyjne produkty umożliwiające oszczędzanie i pozostają nieufni wobec alternatywnych metod inwestowania wolnych środków [Anioła i Gołaś 2012, s. 39]. Jak wynika z przeprowadzonych badań, największy udział w strukturze składników portfela oszczędnościowego wiejskich gospodarstw domowych mają tradycyjne lokaty. Tę formę oszczędzania wskazało 66\% oszczędzających gospodarstw domowych. Otrzymane wyniki są zbieżne z rezultatami badań innych autorów, z których wynika, że 67\% respondentów w 2013 roku posiadało lokaty bankowe [Czapiński i Panek 2015, s. 57].

Kolejną formą oszczędzania jest gotówka. Prawie 50\% oszczędzających respondentów złożyło deklarację, że dysponuje wolnymi środkami w gotówce. W porównaniu z rezultatami badań innych autorów [Czapiński i Panek 2015, s. 57], uzyskano wartości większe o 4 p.p. Otrzymane wyniki potwierdzają to, że wiejskie gospodarstwa domowe cechuje tradycjonalizm i duże „przywiązanie” do gotówki. Sytuacja ta może wynikać również z gorszego dostępu do infrastruktury finansowej na obszarach wiejskich.

Trzecim najczęściej preferowanym produktem oszczędnościowym były jednostki funduszy inwestycyjnych. Ich udział w portfelu oszczędnościowym wiejskich gospodarstw domowych w porównaniu z dwoma wcześniej omówionymi formami oszczędzania jest jednak mały i wynosi 5\%. Do 2007 roku ta forma inwestowania była bardzo popularna w Polsce, jednak po krajowym kryzysie finansowym, w wyniku znacznego zmniejszenia wartości zgromadzonych jednostek w funduszach, obserwuje się mniejsze zainteresowanie gospodarstw domowych tą formą lokowania wolnych środków finansowych. 


\section{4}

Znaczenie pozostałych form oszczędzania było wyraźnie mniejsze. Jedynie $3 \%$ wiejskich gospodarstw domowych województwa małopolskiego zainwestowało wolne środki w obligacje, a 1\% posiadało akcje, które głównie zostały nabyte $\mathrm{w}$ powszechnych programach prywatyzacji. Zdaniem Smyczka [2014, s. 99], niski poziom korzystania $z$ usług finansowych oferowanych przez rynek kapitałowy wynika $\mathrm{z}$ jednej strony $\mathrm{z}$ braku wolnych środków finansowych, a z drugiej z niepewności co do uzyskania korzyści finansowych i z obawy o utratę środków. Wśród pozostałych form oszczędzania należy wymienić zakup nieruchomości oraz polis ubezpieczeniowych. Tylko trzech respondentów zadeklarowało posiadanie produktów finansowych umożliwiających zbieranie środków pieniężnych na przyszłą emeryturę (konta IKE i IKZE).

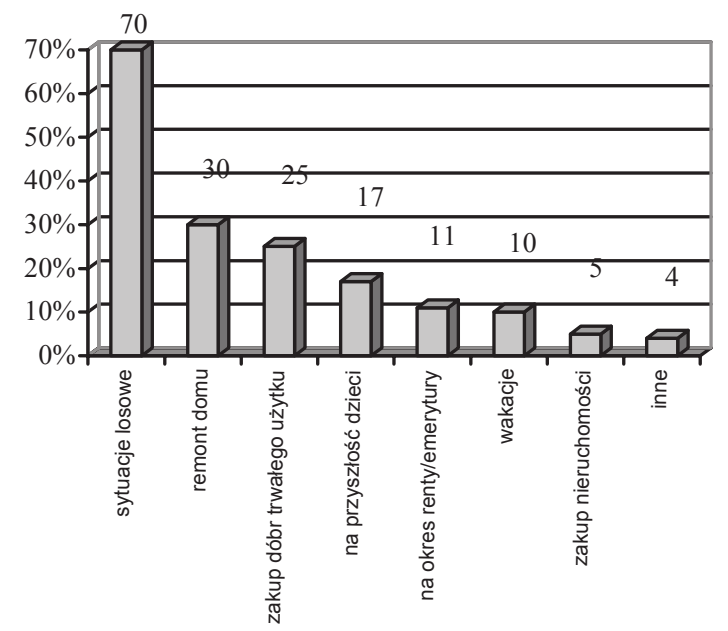

\section{Rysunek 1}

Motywy oszczędzania wiejskich gospodarstw domowych ( $\mathrm{n}=150$; wyrób wielokrotny, 258 wskazań)

Źródło: Badania własne.

Ważnym aspektem zachowań oszczędnościowych są motywy gromadzenia oszczędności. Jak wynika $\mathrm{z}$ danych zaprezentowanych na rysunku 1, głównym celem gromadzonych oszczędności przez wiejskie gospodarstwa domowe były niespodziewane wydatki na sytuacje losowe. Taką odpowiedź wskazało 70\% oszczędzających ankietowanych. Otrzymane rezultaty są zbieżne z wynikami ogólnopolskich badań [Czapiński i Panek 2015, s. 57]. W dalszej kolejności ankietowani przeznaczyli oszczędności na remont domu (30\%) i zakup dóbr trwałego użytku (25\%). Prawie 20\% respondentów oszczędzało na przyszłość dzieci. Niepokojące jest, że tylko $11 \%$ badanych odkładało pieniądze na okres emerytury. Otrzymane wyniki w przypadku tego motywu oszczędzania są zbieżne z rezultatami badań Fundacji Kronenberga [2014, s. 42]. 


\section{Typy strategii oszczędnościowych wiejskich gospodarstw domowych}

W celu wyodrębnienia poszczególnych typów strategii oszczędnościowych wiejskich gospodarstw domowych zastosowano niehierarchiczną metodę analizy skupień - grupowanie metodą k-średnich. Podstawowym kryterium klasyfikacji dokonanej przy zastosowaniu analizy skupień były różne formy oszczędzania i inwestowania. Analizę przeprowadzono na podstawie siedmiu zmiennych: gotówka, lokaty bankowe, fundusze inwestycyjne, dodatkowe fundusze emerytalne, obligacje, akcje oraz pozostałe formy inwestowania. Na podstawie przyjętych kryteriów segmentacji wyodrębniono trzy typy strategii oszczędnościowych wiejskich gospodarstw domowych: T1 - strategię dywersyfikacji, T2 - strategię bierną oraz T3 - strategię konserwatywną, co zostało zaprezentowane na rysunku $2 \mathrm{i}$ w tabeli 1 . W tabeli 2 przedstawiono podstawowe informacje dotyczące wybranych czynników determinujących zachowania oszczędnościowe wiejskich gospodarstw domowych w poszczególnych typach.
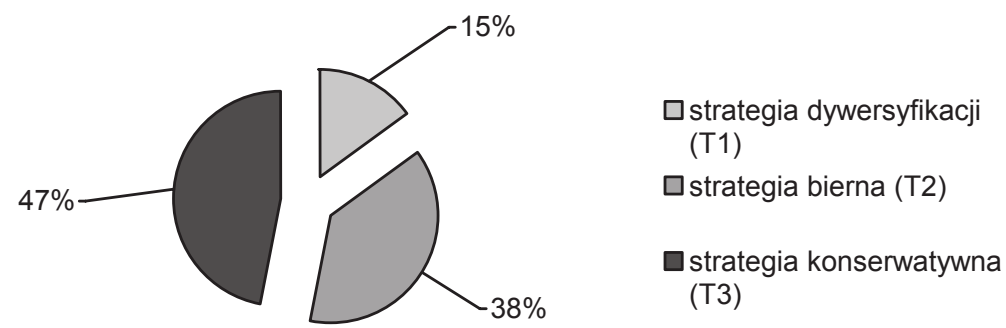

Rysunek 2

Strategie oszczędnościowe wiejskich gospodarstw domowych $(n=150)$

Źródło: Badania własne.

\section{Tabela 1}

Typy strategii oszczędnościowych w wiejskich gospodarstwach domowych (częstość deklarowania posiadania poszczególnych produktów oszczędnościowych - \% gospodarstw; $n=150$ )

\begin{tabular}{|l|c|c|c|}
\hline \multirow{2}{*}{ Forma oszczędności } & \multicolumn{3}{|c|}{ Typ strategii } \\
\cline { 2 - 4 } & T1-dywersyfikacji & T2 - bierna & T3-konserwatywna \\
\hline Lokaty w bankach & 75 & 55 & 70 \\
\hline Gotówka & 80 & 41 & 38 \\
\hline Dodatkowe fundusze emerytalne & 9 & 0 & 1 \\
\hline Fundusze inwestycyjne & 9 & 2 & 7 \\
\hline Obligacje & 9 & 2 & 3 \\
\hline Akcje & 9 & 0 & 0 \\
\hline Inne & 9 & 5 & 3 \\
\hline
\end{tabular}

Źródło: Badania własne. 
Tabela 2

Czynniki determinujące poszczególne typy strategii oszczędnościowych wiejskich gospodarstw domowych $(n=150)$

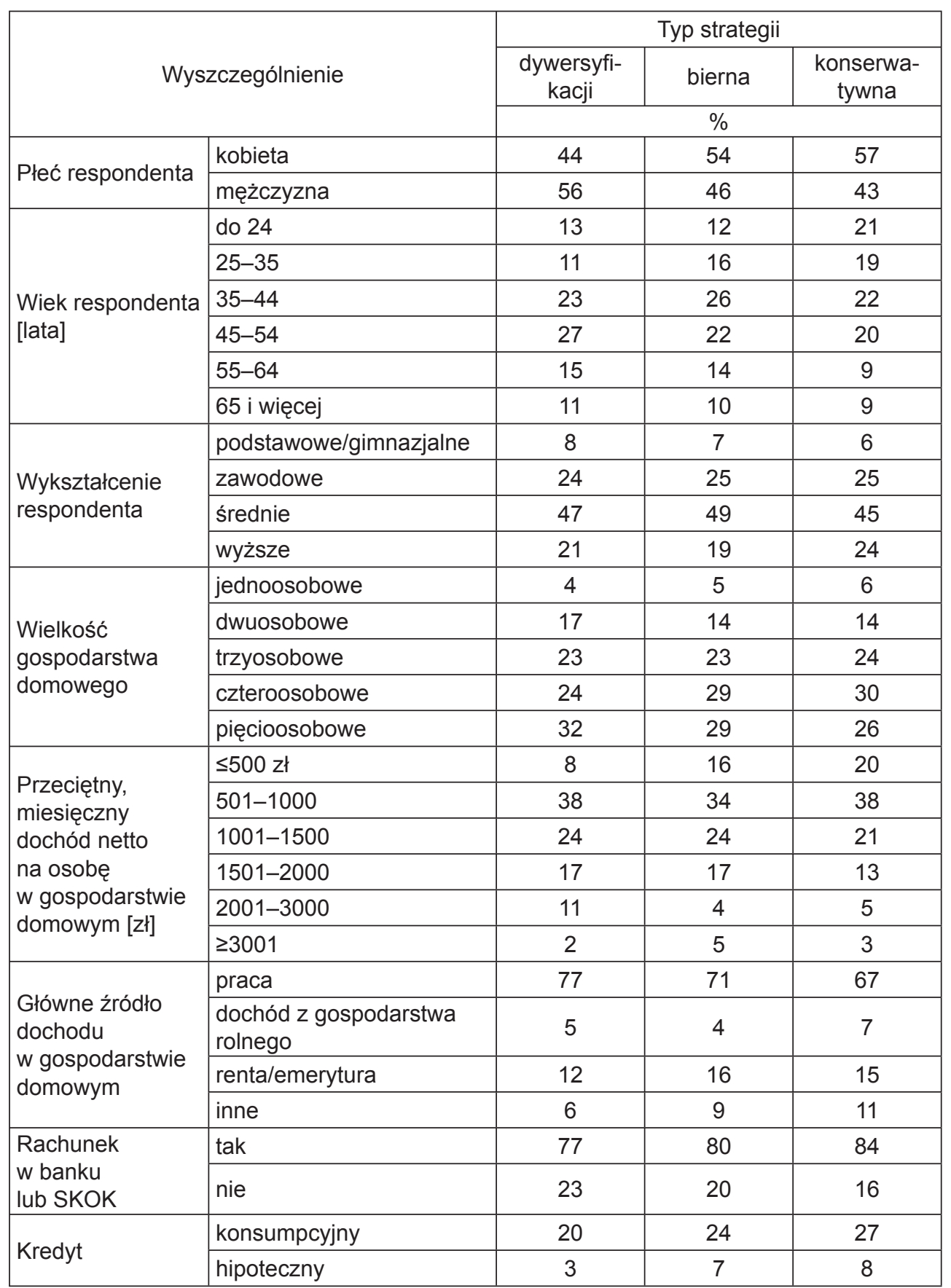

Źródło: Badania własne. 
Wiejskie gospodarstwa domowe województwa małopolskiego charakteryzują się mniejszym zróżnicowaniem stosowanych strategii oszczędnościowych, w porównaniu z wynikami ogólnopolskimi. Jak wynika z badań Anioły i Gołasia [2013a, s. 23], w polskich gospodarstwach domowych zidentyfikowano aż sześć strategii. W analizowanej grupie podmiotów nie stwierdzono strategii: wybitnie konserwatywnej, agresywnej i małego ryzyka. Wynika to z tego, że portfel oszczędnościowy wiejskich gospodarstw domowych nie jest zdywersyfikowany i tworzą go głównie lokaty bankowe i gotówka.

Jedną z wyodrębnionych strategii była strategia dywersyfikacji (T1) reprezentowana przez najmniej liczną grupe gospodarstw (15\%), cechująca się najwyższą stopą oszczędzania. W zdywersyfikowanym portfelu oszczędnościowym wolne środki przechowywane były w formie gotówkowej $(72 \%$ badanych gospodarstw) oraz na bankowych rachunkach terminowych (75\%). W porównaniu z pozostałymi wyodrębnionymi grupami w strukturze portfela oszczędnościowego większe znaczenie miały inne formy oszczędzania, także jednostki funduszy inwestycyjnych czy inwestycje w akcje. Respondenci z tej grupy, w porównaniu z pozostałymi grupami strategii, rzadziej deklarowali posiadanie kredytów hipotecznych i konsumpcyjnych, reprezentowali również postawę, że wolą oszczędzać niż żyć „na kredyt”. W tej grupie znajdowali się głównie mężczyźni, osoby w wieku 35-54 lat oraz z wykształceniem zawodowym i średnim. Dominowały w niej rodziny wieloosobowe. Gospodarstwa domowe reprezentujące strategię T1 cechują się najkorzystniejszą sytuacją dochodową.

Kolejny wyodrębniony typ strategii oszczędnościowej stanowi strategia bierna (T2), którą reprezentuje prawie $40 \%$ badanych. Grupa ta charakteryzuje się najniższą stopą oszczędzania. Prawie $60 \%$ osób z tej grupy posiadało lokaty bankowe, a 39\% miało oszczędności w gotówce. Wykorzystanie alternatywnych do lokat instrumentów finansowych w tej grupie było również najmniejsze. W porównaniu z wcześniej omówioną strategią (T1), respondenci reprezentujący strategię T2 częściej korzystali z różnych rodzajów kredytów. Były to kobiety, badani w wieku 35-54 lat, z wykształceniem średnim. Strategię T2 preferują głównie renciści i emeryci.

Jak wynika z przeprowadzonych badań, najliczniejszą grupą osób są respondenci reprezentujący strategię T3 - konserwatywną (47\% badanej próby). Ta grupa osób charakteryzuje się najmniejszym udziałem jednostek, które wolne środki przechowują w gotówce. Jednocześnie są to osoby, które charakteryzują się najwyższym współczynnikiem ubankowienia ze wszystkich analizowanych grup. Prawie 3/4 respondentów reprezentujących strategię konserwatywną posiada również lokatę w banku. Udział pozostałych instrumentów finansowych w portfelu oszczędnościowym jest większy niż u osób reprezentujących stosujących strategię T2, mniejszy u osób wybierających strategię T1. Osoby zakwa- 
lifikowane do strategii T3, w porównaniu z pozostałymi, najczęściej korzystały z kredytów. Jak wynika z danych z tabeli 2, strategia ta cechuje głównie kobiety, osoby najmłodsze, rodziny czteroosobowe oraz najuboższe gospodarstwa domowe. W tej grupie respondentów udział osób, których głównym źródłem dochodu są środki pochodzące z pracy we własnym gospodarstwie rolnym lub pozostałych źródeł (zasiłki, pomoc osób z zagranicy itp.) jest największy.

\section{Podsumowanie}

Przeprowadzone badania umożliwiły charakterystykę wybranych zachowań oszczędnościowych wiejskich gospodarstw domowych w województwie małopolskim oraz identyfikację typów strategii oszczędnościowych realizowanych przez te gospodarstwa.

1. Badane wiejskie gospodarstwa domowe charakteryzują się małą skłonnością do oszczędzania, jednak nie jest ona mniejsza niż średnia dla całego kraju. Prawie $60 \%$ respondentów nie posiadało oszczędności. Z kolei w grupie oszczędzających gospodarstw tylko $1 / 3 \mathrm{z}$ nich posiadała oszczędności na poziomie wyższym niż trzymiesięczne dochody gospodarstwa.

2. Głównymi formami gromadzenia oszczędności przez analizowane wiejskie gospodarstwa domowe były lokaty bankowe i gotówka. Zainteresowanie pozostałymi formami oszczędzania, takimi jak: papiery wartościowe, lokaty w dobrach materialnych, polisy ubezpieczeniowe było niewielkie.

3. Oszczędności ankietowanych $\mathrm{w}$ głównej mierze stanowiły rezerwę na nieprzewidziane zdarzenia losowe, remont domu oraz zakup dóbr trwałego użytku. Tylko $11 \%$ badanych gospodarstw gromadziło oszczędności „na starość”. W tym przypadku zauważono różnice między Małopolską a resztą kraju w zakresie zachowań oszczędnościowych wiejskich gospodarstw domowych, w których gromadzenie oszczędności na okres emerytury było, poza sytuacjami losowymi, drugim najważniejszym motywem oszczędzania.

4. W przypadku badanych gospodarstw zidentyfikowano tylko trzy strategie: konserwatywną, bierną oraz dywersyfikacji. Dominującą spośród sześciu możliwych była strategia konserwatywna.

\section{Literatura}

ANDO A., MODIGLIANI F., 1963: The Life Cycle Hypothesis of Saving: Aggregate Implications and Tests, The American Economic Review 53(1), 1, 55-84. 
ANIOŁA P., GOŁAŚ Z., 2012: Zastosowanie wielowymiarowych metod statystycznych w typologii strategii oszczędnościowych gospodarstw domowych w Polsce, Materiały i Studia NBP 282.

ANIOŁA P., GOŁAŚ Z., 2013a: Strategie oszczędnościowe gospodarstw domowych w Polsce, Journal of Agribusiness and Rural Development 1(27), 19-31.

ANIOŁA P., GOŁAŚ Z., 2013b: Zachowania oszczędnościowe gospodarstw domowych w Polsce, Wydawnictwo Uniwersytetu Przyrodniczego w Poznaniu, Poznań.

BAŃBUŁA P., 2006: Oszczędności i wybór międzyokresowy - podejście behawioralne, Materiały i Studia NBP 208.

BYWALEC Cz., 2009: Ekonomika i finanse gospodarstw domowych, Wydawnictwo Naukowe PWN, Warszawa.

CZAPIŃSKI J. (red.), PANEK T., 2015: Diagnoza Społeczna 2015. Warunki i jakość życia Polaków, Contemporary Economics 9(4).

DEIRDRE E., 2007: Financial Inclusion and Capability in Rural Scotland, Scottish Council Foundation, Edinburgh.

Fundacja Kronenberga, 2014: Postawy Polaków wobec oszczędzania, PBS, Warszawa.

GARCZARCZYK J., MOCEK M., SKIKIEWICZ R., 2014: Zachowania gospodarstw domowych na rynku ustug finansowych $w$ warunkach zmiennej koniunktury, Cedewu.pl, Warszawa.

GUS, 2014: Rocznik statystyczny województw 2013, Zakład Wydawnictw Statystycznych, Warszawa.

KATA R., 2010: Korzystanie przez rolników i przedsiębiorców wiejskich z ustug bankowych - analiza preferencji i ograniczeń, Zagadnienia Ekonomiki Rolnej 1(322), 143-162.

KATA R., WALENIA A., PYRKOSZ D.S., 2015: Wykluczenie finansowe ludności wiejskiej $w$ Polsce, Journal of Agribusiness and Rural Development 4(38), 1-10.

KORENIK D., 2003: Oszczędzanie indywidualne w Polsce, Wydawnictwo Akademii Ekonomicznej we Wrocławiu, Wrocław.

KUŚMIERCZYK K., 2011: Ekonomiczne $i$ demograficzne uwarunkowania konsumpcji w regionach, [w:] A. Kusińska (red.), Konsumpcja a rozwój społeczno-gospodarczy regionów w Polsce, PWE, Warszawa, 31-82.

MACIEJASZ-ŚWIATKIEWICZ M., 2012: Zachowania finansowe gospodarstw domowych, [w:] E. Bogacka-Kisiel (red.), Finanse osobiste. Zachowania - produkty - strategie, Wydawnictwo Naukowe PWN, Warszawa, 38-64.

SMYCZEK S., 2012: Nowe trendy w zachowaniach konsumentów na rynkach finansowych, Placet, Warszawa.

SMYCZEK S., 2014: Przejawy unowocześniania konsumpcji na rynkach finansowych, [w:] E. Kieżel, S. Smyczek (red.), Zachowania konsumentów. Procesy unowocześniania konsumpcji, Oficyna a Wolters Kluwer business, Warszawa, 97-118.

STANISZ A., 2007: Przystępny kurs statystyki z zastosowaniem STATISTICS PL na przykładach z medycyny. Tom 3. Analizy wielowymiarowe, StatSoft, Kraków.

TNS Polska, 2014: Oszczędzanie dtugoterminowe - opinie, postawy i oczekiwania polskiego społeczeństwa, Warszawa. 


\begin{abstract}
Abstrakt
W opracowaniu podjęto próbę identyfikacji i charakterystyki poszczególnych typów strategii oszczędnościowych wiejskich gospodarstw domowych w województwie małopolskim, a także określenia motywów, którymi kierują się konsumenci podczas podejmowania decyzji o oszczędzaniu. $\mathrm{W}$ badaniach wykorzystano źródła pierwotne (kwestionariusz wywiadu - 394 respondentów) oraz wtórne.

Na podstawie przeprowadzonych badań można stwierdzić, że wiejskie gospodarstwa domowe charakteryzują się małą skłonnością do oszczędzania. Prawie $60 \%$ respondentów nie posiadało jakichkolwiek oszczędności. Głównymi formami gromadzenia oszczędności przez wiejskie gospodarstwa domowe były lokaty bankowe i gotówka. Zgromadzone środki pieniężne stanowiły rezerwę na nieprzewidziane zdarzenia losowe, remont domu oraz zakup dóbr trwałego użytku. Wiejskie gospodarstwa domowe różnią się pod względem realizowanych strategii oszczędzania. W wyniku przeprowadzonej analizy wyodrębniono trzy strategie oszczędnościowe, wśród których dominującą była konserwatywna.
\end{abstract}

Słowa kluczowe: zachowania oszczędnościowe, wiejskie gospodarstwa domowe, województwo małopolskie

\title{
Typology of saving strategies of rural households (on the example of the Malopolska Province)
}

\begin{abstract}
The study is an attempt to identify and characterise different types of saving strategies of rural households in the Małopolska Province and to define the motives standing behind the decision to start saving. Primary (interview questionnaire - 394 respondents) and secondary sources were used.

The conducted research allows for the conclusion that rural households in the Małopolska Province show low propensity to save. Almost $60 \%$ respondents did not have any savings. The main forms of collecting savings by rural households are bank deposits and cash. The savings were mostly a reserve for unforeseen events, house renovations, and the purchase of durable goods. Rural households vary in terms of saving strategy. The dominant strategy was the conservative one.
\end{abstract}

Key words: saving behaviour, rural households, Małopolska Province 